\title{
New Astyanax from the upper rio Tapajós drainage, Central Brazil (Characiformes: Characidae)
}

\author{
Vinicius A. Bertaco* and Valdener Garutti**
}

Astyanax utiariti, new species, is described from the upper rio Tapajós drainage, Mato Grosso, Brazil. Astyanax utiariti has a horizontally oval black humeral spot, a lozenge-shaped caudal-peduncle spot, continuing to the tip of the middle caudal-fin rays, and two brown bars in the humeral region that allows its inclusion in the A. bimaculatus species group. It also possesses a black stripe extending along midlateral body. The new species is distinguished from its congeners by a reticulate scale pattern, a black longitudinal stripe, toothless maxilla, larger dentary teeth and teeth of the inner row of the premaxilla with five to seven cusps, body depth 33.3-39.9\% of standard length (SL), head length (HL) 23.9-26.4\% of SL, caudal-peduncle depth $12.0-13.4 \%$ of SL, orbital diameter $28.5-34.3 \%$ of HL, interorbital width $32.7-38.4 \%$ of HL, 36-38 perforated scales along the lateral line, and 22-26 branched anal-fin rays.

Astyanax utiariti, nova espécie, é descrita da drenagem do alto rio Tapajós, Mato Grosso, Brasil. Astyanax utiariti tem uma mancha umeral preta horizontalmente ovalada, uma mancha losangular preta no pedúnculo caudal continuada até a extremidades dos raios caudais medianos e duas barras marrons na região humeral, que permite sua inclusão no grupo de espécies $A$. bimaculatus. Também possui uma faixa preta estendida ao longo do meio do corpo. A nova espécie distingue-se de suas congêneres pelo padrão reticulado nas escamas, uma faixa preta longitudinal, maxilar sem dentes, dentes maiores do dentário e dentes da série interna do pré-maxilar com cinco a sete cúspides, altura do corpo de 33,3-39,9\% do comprimento padrão (CP), comprimento da cabeça (CC) de 23,9-26,4\% do CP, altura do pedúnculo caudal 12,0-13,4\% do CP, diâmetro orbital de 28,5-34,3\% do CC, largura interorbital de 32,7-38,4\% do CC, 36-38 escamas perfuradas ao longo da linha lateral e 22-26 raios ramificados na nadadeira anal.

Key words: Neotropical, Amazon basin, Astyanax bimaculatus, Taxonomy, fish.

\section{Introduction}

The genus Astyanax Baird \& Girard is a speciose group of Neotropical characid fishes, comprising almost one hundred described species (Bertaco \& Lucena, 2006) and occurring in diverse habitats within freshwater drainages from the southern United States to central Argentina. The nominal species currently assigned to Astyanax probably do not represent a monophyletic entity (Weitzman \& Malabarba, 1998), a situation that has long been recognized for the genus (Rosen, 1972). Astyanax was revised by Eigenmann $(1921,1927)$, whose accounts still constitute the sole all-inclusive review of the genus. The current definition of Astyanax is based on a combination of characters proposed by Eigenmann (1917).

In the last years, Garutti $(1995,1998,1999,2003)$ and Garutti $\&$ Britski $(1997,2000)$ revised a group of Astyanax species with a combination of the following characters: a horizontally oval, black humeral spot, a lozenge shaped caudal-peduncle spot, continuing to the tip of the middle caudal rays, and two brown vertical bars in the humeral region. The new species described herein is included in this species group.

The new species is described based on new specimens

\footnotetext{
*Laboratório de Ictiologia, Museu de Ciências e Tecnologia, Pontifícia Universidade Católica do Rio Grande do Sul, Av. Ipiranga 6681, Caixa Postal 1429, 90619-900 Porto Alegre, RS, Brazil. ubertaco@pucrs.br

**Pesquisador Visitante-CNPq, Universidade Federal de Mato Grosso, Instituto de Ciências e Letras do Médio Araguaia, Pontal do Araguaia, Mato Grosso, Brazil. valdenergarutti@yahoo.com.br
} 


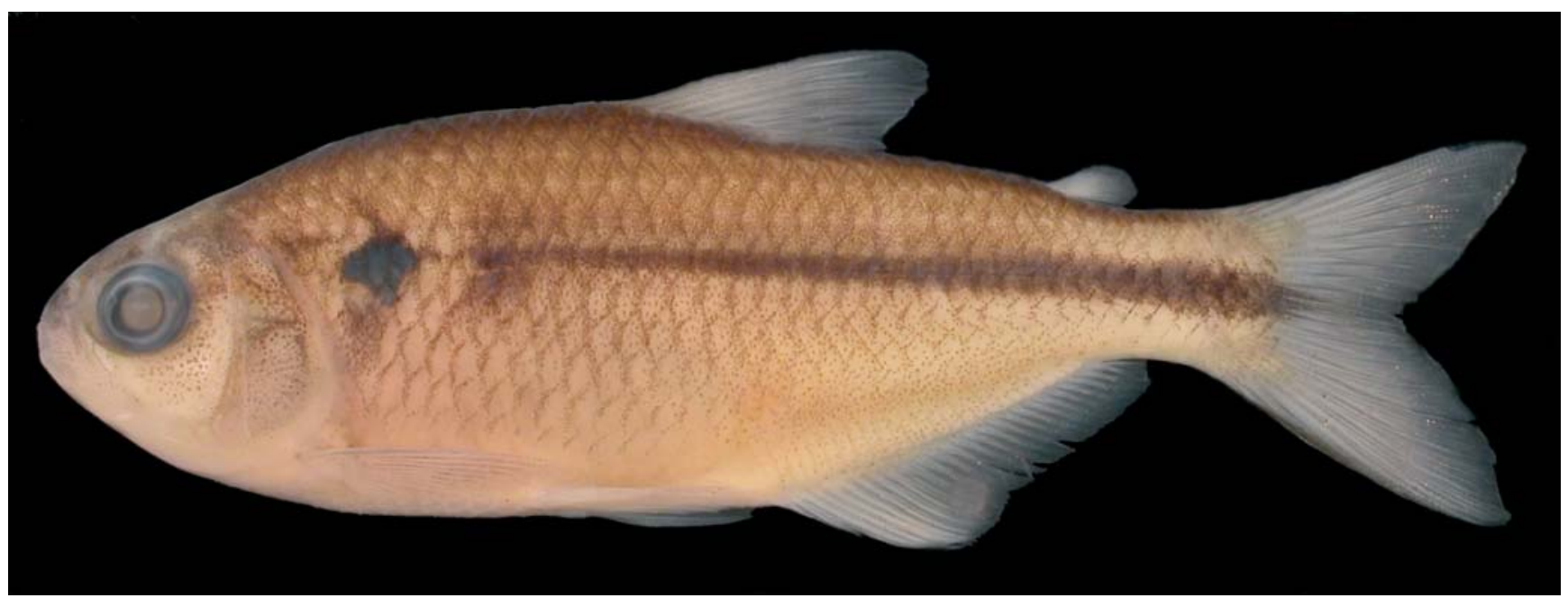

Fig. 1. Astyanax utiariti, MCP 40040, holotype, male, $67.8 \mathrm{~mm}$ SL; rio Papagaio, tributary of rio Juruena, upper rio Tapajós drainage, Sapezal, Mato Grosso, Brazil.

collected in the upper rio Tapajós drainage during a recent expedition to some of the southern tributaries of the Amazon River in the Central and Western regions of Brazil.

\section{Material and Methods}

Counts and measurements follow Fink \& Weitzman (1974), with the exception of the number of scale rows below the lateral line, which were counted from the scale row ventral to the lateral line to the scale row nearest to the first pelvic-fin ray. Counts of vertebrae, supraneurals, gill-rakers of the first arch, and procurrent caudal-fin-rays were taken from three cleared and stained (c\&s) paratypes prepared according to the method of Taylor \& Van Dyke (1985). Values for the holotype are indicated by an asterisk. Statistical tests of differences between the sexes were performed. Tooth counts were taken for all type specimens. Vertebral counts include the four vertebrae of the Weberian apparatus and the terminal half centrum, counted as one vertebra. Lower and upper jaws of one c\&s paratype were prepared for scanning electronic microscopy (SEM) analysis.

Measurements were taken point to point with an electronic caliper on the left side of specimens. All measurements other than standard length (SL) are expressed as percents of SL except subunits of the head, which are expressed as percents of head length (HL).

The specimens examined belong to the Academy of Natural Sciences, Philadelphia (ANSP), Museo de Biología de la Universidad Central de Venezuela, Caracas (MBUCV), Museu de Ciências e Tecnologia, Pontifícia Universidade Católica do Rio Grande do Sul, Porto Alegre (MCP), Museum of Comparative Zoology, Cambridge (MCZ), Museu Nacional, Rio de Janeiro (MNRJ), Museu de Zoologia da Universidade de São Paulo, São Paulo (MZUSP), and National Museum of Natural History, Smithsonian Institution (USNM).

\section{Astyanax utiariti, new species}

Figs. 1 and 2

Holotype. MCP 40040, $67.8 \mathrm{~mm}$ SL, male, rio Papagaio at Pubi beach, tributary of rio Juruena, upper rio Tapajós drainage, Sapezal, Mato Grosso, Brazil, 1333’35"S 58 24’31"W, 13-14 Jul 2004, ACSI - Brazilian Transcontinental Expedition.

Paratypes. ANSP 185226, 15, 57.8-64.0 mm SL, MCP 40041, 64 (3 c\&s), 56.2-79.3 mm SL, MNRJ 29859, 15, 60.1-67.0 mm SL, collected with the holotype. MZUSP 5177, 6, 47.2-66.9 mm SL, rio Papagaio above Salto Utiariti, tributary of rio Juruena, upper rio Tapajós drainage, Mato Grosso, Brazil, approx. $13^{\circ} 02^{\prime}$ S 58 $16^{\prime}$ W, Nov 1966, K. Lenko \& P. Pereira.

Non-type material. MCP 40875, 12, 56.7-76.3 mm SL, collected with the holotype.

Diagnosis. The horizontally elongate oval, black humeral spot, the lozenge shaped caudal-peduncle spot continued into middle caudal-fin rays, and two brown bars in the humeral region, distinguish Astyanax utiariti from most congeners and include it in the A. bimaculatus species group. The new species is distinguished from species of this group by the following combination of characters: a reticulate scale pattern, a black longitudinal stripe, a toothless maxilla, larger dentary teeth, teeth of the inner row of the premaxilla with five to seven cusps, body depth 33.3-39.9\% of SL, predorsal distance $51.7-55.5 \%$ of SL, caudal peduncle depth $12.0-13.4 \%$ of SL, head length $23.9-26.4 \%$ of SL, orbital diameter 28.5 $34.3 \%$ of HL, interorbital width $32.7-38.4 \%$ of HL, 36-38 perforated scales along the lateral line, and 22-26 branched anal-fin rays (25-29 total). 
Description. Morphometric data are summarized in Table 1. Body compressed and elongate; greatest body depth usually anterior to dorsal-fin origin. Dorsal head profile from upper lip to vertical through middle orbit convex, and from latter point to supraocciptal tip straight or slightly concave. Profile convex from supraocciptal tip to base of last dorsal-fin ray, and straight towards adipose-fin origin. Ventral head profile convex. Ventral body profile slightly convex to nearly straight from pectoral-fin origin to pelvic-fin origin, and straight to slightly concave towards anal-fin origin. Body profile along anal-fin base slanted posterodorsally. Caudal peduncle elongate, nearly straight to slightly concave along dorsal and ventral margins.

Head small. Mouth terminal, lower jaw slightly longer than upper jaw. Maxilla extending posterior to vertical through anterior margin of orbit, slightly curved and aligned at angle of approximately 60 degrees to longitudinal body axis. Anterodorsal border of maxilla concave and posterodorsal border slightly convex. Anteroventral and posteroventral borders convex.

Two tooth rows on premaxilla. Outer row with three or five, tricuspid or pentacuspid teeth, with central cusp longer. Inner row with five teeth, gradually decreasing in size from first to fourth tooth; last tooth smaller, with five to seven cusps, central cusp twice or three times longer and broader than other cusps. Maxilla without teeth. Only three specimens with one conical or tricuspid tooth $(n=107)$. Three to five anteriormost dentary teeth larger, with five to seven cusps, followed by one or two medium-sized teeth with five cusps, and six teeth with one to three cusps or conical; central cusp in all teeth two to three times longer and broader than other cusps. All cusp tips slightly curved towards inside of mouth (Fig. 2).

Scales cycloid, moderately large. Lateral line complete. Scales in longitudinal series 36-38 $\left(36^{*}\right.$, mean $\left.=37.0, \mathrm{n}=23\right)$. Scale rows between dorsal-fin origin and lateral line 6-7 (7*, mean $=7, \mathrm{n}=23$ ); scale rows between lateral line and pelvicfin origin 5-6 $\left(5^{*}\right.$, mean $\left.=5, \mathrm{n}=23\right)$. Predorsal scales 11-13, arranged in regular series $\left(11^{*}\right.$, mean $\left.=11.7, \mathrm{n}=21\right)$. Scale rows around caudal peduncle $14-18\left(14^{*}\right.$, usually 16 , mean $=$ $15.7, \mathrm{n}=23)$. Scale sheath along anal-fin base 9-12 $\left(10^{*}\right)$ scales in single series, extending to base of eleventh to thirteenth branched ray.

Dorsal-fin rays ii, $9 *(n=23)$; first unbranched ray approximately one-half length of second ray. Dorsal-fin origin located posterior to middle of SL and posterior to vertical through pelvic-fin origin. Adipose-fin origin located approximately at vertical through insertion of base of five to seven last anal-fin rays.

Anal-fin rays iii-iv, $22-25$ ( $24^{*}$, one specimen with 26 , mean $=23.6, \mathrm{n}=23$ ). Anal-fin profile smoothly concave in females, nearly straight in males. Anal-fin origin posterior to vertical through base of last dorsal-fin ray in females, and anterior to vertical through base of last dorsal-fin ray in males. Anal-fin rays of males bearing one pair of small, elongate, retrorse

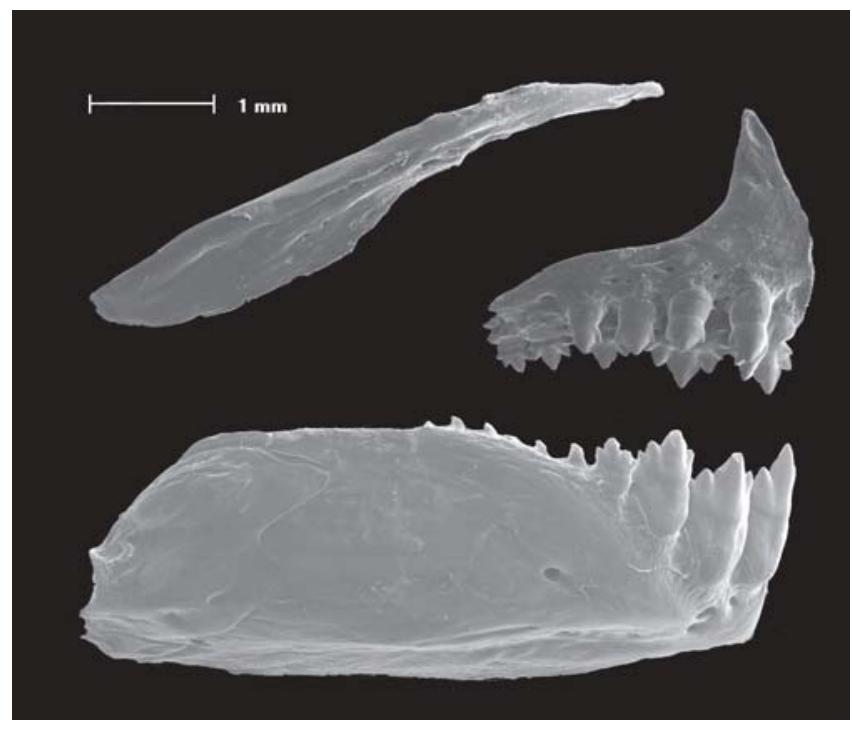

Fig. 2. Astyanax utiariti, MCP 40041, paratype, male, $64.5 \mathrm{~mm}$ $\mathrm{SL}, \mathrm{c} \&$ s specimen. Scanning electron microscopy of left side upper and lower jaws.

bony hooks along posterolateral border of each segment of lepidotrichia, usually along last unbranched ray and eighth branched rays. Hooks usually located along posteriormost branch and distal half to two-thirds length of each ray.

Pectoral-fin rays i,11-14 $\left(11^{*}\right.$, mean $\left.=11.6, \mathrm{n}=23\right)$. Pectoral-fin tip reaching or surpassing pelvic-fin origin in males but not in females. Pelvic-fin rays i, $7 *$ (three specimens with $\mathrm{i}, 6, \mathrm{i} ; \mathrm{n}=23)$. Pelvic-fin origin located anterior to vertical through dorsal-fin origin. Caudal-fin forked, with 19 principal rays. Dorsal procurrent rays $12(n=3)$. Ventral procurrent rays 10$11(\mathrm{n}=3)$.

Precaudal vertebrae 17; caudal vertebrae 17-18; total vertebrae 34-35. Supraneurals 5. Gill-rakers on dorsal limb of outer gill arch 7-8, and on ventral limb $12(\mathrm{n}=3)$.

Color in alcohol. Dorsal and dorsolateral portion of head and body dark brown. Dark chromatophores scattered on infraorbitals and opercle. Scales on lateral surface of body bordered with dark brown chromatophores forming reticulate pattern. A black humeral spot horizontally oval, located over second to sixth scales on horizontal row, and extending over two horizontal series of scales above lateral line. Two brown and diffuse vertical bars in humeral region; first located over humeral spot and extending over five or six horizontal series of scales, including lateral line. Second vertical bar, located on first series of scales above lateral line, between seventh to tenth series of scales and extending over two or three horizontal series of scales. A black stripe extending along midlateral body from humeral spot to middle caudal-fin rays, located over second series of scales above lateral line on anterior portion of body, and over lateral line scales on the caudal peduncle. In some specimens, the stripe extends from 
Table 1. Morphometric data of holotype (H, male) of Astyanax utiariti, and paratypes (MCP 40041) from rio Papagaio, tributary of rio Juruena, upper rio Tapajós drainage, Sapezal, Mato Grosso, Brazil. ( $\mathrm{N}=23$ including the holotype; $\mathrm{m}$, males; $\mathrm{f}$, females).

\begin{tabular}{lccccc}
\hline \multicolumn{1}{c}{$\mathrm{H}$} & $\mathrm{N}$ & Range & Mean & SD \\
\hline Standard length (mm) & 67.8 & 23 & $57.8-79.3$ & - & - \\
& Percents of Standard length \\
Predorsal distance & 52.9 & 23 & $51.7-55.5$ & 53.6 & 1.12 \\
Prepelvic distance & 45.0 & 23 & $45.0-49.6$ & 47.1 & 1.24 \\
Prepectoral distance & 25.3 & 23 & $24.6-27.6$ & 26.1 & 0.74 \\
Preanal distance & 64.1 & 23 & $62.9-69.5$ & 65.8 & 2.17 \\
Depth at dorsal-fin origin & 34.9 & 23 & $33.3-39.9$ & 36.5 & 1.67 \\
Caudal peduncle depth & 12.5 & 23 & $12.0-13.4$ & 12.4 & 0.33 \\
Caudal peduncle length & 12.5 & 23 & $11.4-14.2$ & 12.8 & 0.78 \\
Anal-fin base length & 29.0 & 23 & $25.9-30.8$ & 28.2 & 1.30 \\
Dorsal-fin length & 26.8 & 23 & $24.6-28.5$ & 26.7 & 1.18 \\
Pelvic-fin length (m) & 19.2 & 12 & $17.4-19.8$ & 18.9 & 0.80 \\
Pelvic-fin length (f) & - & 11 & $15.2-17.4$ & 16.4 & 0.68 \\
Pectoral-fin length (m) & 23.0 & 12 & $21.3-25.1$ & 23.0 & 0.97 \\
Pectoral-fin length (f) & - & 11 & $20.1-23.0$ & 21.0 & 0.78 \\
Head length & 25.8 & 23 & $23.9-26.4$ & 25.3 & 0.78 \\
\multicolumn{7}{l}{ Snout length } & Percents of Head length & & \\
Upper jaw length & 21.7 & 23 & $19.8-23.6$ & 21.7 & 1.06 \\
Orbital diameter & 38.2 & 23 & $38.2-43.4$ & 40.4 & 1.54 \\
Interorbital width & 28.9 & 23 & $28.5-34.3$ & 31.0 & 1.44 \\
\hline
\end{tabular}

second vertical bar. Midlateral stripe wide, width becoming gradually narrower forward; maximum width on the caudal peduncle, including the series of lateral line scales and first series above; width of about a scale at the vertical through dorsal-fin tip, and $1 / 2$ of scale near the second vertical bar. Stripe relatively darkest posteriorly and becoming more diffuse anteriorly. All fins with scattered dark chromatophores (Fig. 1).

Sexual dimorphism. Males of $A$. utiariti are easily recognized by the presence of bony hooks on the anal- and pelvicfin rays (see Description). All males examined possess bony hooks along these fins. Males and females also differ in proportional pectoral- and pelvic-fin lengths (Table 1) and analfin shape, which is concave in females and nearly straight in males. Females also attain larger body sizes than males (69.8$79.3 \mathrm{~mm} \mathrm{SL}$, mean $=75.1, \mathrm{n}=11$ vs $57.8-67.8 \mathrm{~mm} \mathrm{SL}$, mean $=$ $64.6, \mathrm{n}=12$, respectively). Males lack gill gland on first gill arch.

Distribution. Astyanax utiariti is known only from rio Papagaio, a tributary of the upper rio Juruena, upper rio Tapajós drainage, Mato Grosso, Brazil.

Etymology. The name, utiariti, is in reference to the Salto Utiariti, an indigenous word that means in the Pareci nation's language "place of clever people" (utia = clever; halíti = people). Pareci tribe is an indigenous group that lives in the region of the upper rio Tapajós drainage, at type locality. A noun in apposition.
Ecological notes. At the type-locality the rio Papagaio is large and has several waterfalls, with crystalline water, segments with rapids, a well developed riparian vegetation, and a substrate of stones, rocks, and sand. The specimens of $A$. utiariti were collected with a seine and gill-nets along the left bank of the river in semilentic stretches. On the right bank of the rio Papagaio is located the "Área Indígena Utiariti," a Brazilian natural reserve.

\section{Discussion}

Astyanax utiariti possesses a black, oval humeral spot, that is horizontally elongate, a black, lozenge-shaped caudalpeduncle spot continued into the middle caudal-fin rays, and two brown bars on the humeral region. This new taxon has the basic characters used by Garutti (1995) to diagnose the Astyanax bimaculatus species group, which includes several undescribed and described species of Astyanax from the rio Paraná, rio São Francisco, and rio Amazonas basins. Furthermore, $A$. utiariti possesses a black stripe extending along midlateral body.

These characteristics allow its inclusion in one of the two putative sub-groups recognized by Garutti (1999) within the bimaculatus species group, the sub-group of species with a black lateral stripe. This sub-group currently includes ten species: A. argyrimarginatus Garutti, $A$. clavitaeniatus Garutti, A. goyacensis Eigenmann, $A$. incaicus Tortonese, $A$. novae Eigenmann, A. rupununi Fowler, A. saltor Travasssos, A. siapae Garutti, A. unitaeniatus Garutti, and A. utiariti. The statement of Garutti (1999) that $A$. saltor and A. incaicus lack a black lateral stripe by is in error.

Astyanax utiariti differs from $A$. rupununi by the width of the black lateral stripe (stripe width $1 / 2$ of scale depth $v s$ stripe width $1 / 5$ of scale depth, respectively), larger caudal peduncle depth (12.0-13.4 vs 9.1-9.2\% of SL), and more cusps on the largest dentary teeth (five to seven cusps $v s$ five cusps). It differs from $A$. clavitaeniatus, $A$. incaicus, and $A$. siapae by the absence of a maxillary tooth ( $v s$ one maxillary tooth), black lateral stripe width (stripe width $1 / 2$ of scale depth $v s$ black club-shaped lateral stripe, i.e. larger width on caudal peduncle, strongly narrowed forward, reduced to $1 / 5$ or less of a scale between vertical through dorsal-fin tip and vertical through dorsal-fin origin), shallower body (33.3-39.9 vs 37.445.5 and $36.6-44.4 \%$ of SL). Astyanax utiariti differs from $A$. clavitaeniatus and $A$. siapae by a deeper caudal peduncle (12.0-13.4 vs 10.3-12.3 and 7.3-11.3\% of SL), respectively. It further differs from $A$. clavitaeniatus by smaller orbital diameter (28.5-34.3 vs 31.9-38.1\% of HL), and smaller interorbital width (32.7-38.4 vs 36.1-49.3\% of HL), and from A. siapae by having fewer lateral line scales (36-38 vs 38-45). It differs from A. argyrimarginatus and $A$. unitaeniatus, by the absence of maxillary teeth ( $v s$ one maxillary tooth), and by having fewer lateral line scales (36-38 vs 42-46 and 41-44, respectively). It differs from A. goyacensis by larger orbital diameter (28.534.3 vs $25.5-29.8 \%$ of HL), smaller interorbital width (32.7-38.4 
vs 37.4-34.3\% of HL), and larger number of cusps of the premaxilla inner row teeth (five to seven $v$ f five cusps). Astyanax utiariti differs from $A$. novae by the smaller orbital diameter (28.5-34.3 vs 32.1-42.9\% of HL), smaller interorbital width (32.738.4 vs 36.4-45.8\% of HL), shallower body (33.3-39.9 vs 37.6$47.2 \%$ of SL), and by having more lateral line scales (36-38 vs 32-37). Finally, A. utiariti differs from A. saltor (whose typelocality is Cachimbo, PA, rioTapajós drainage) by having more anal-fin rays (25-29 vs 23), shallower body (33.3-39.9 vs 41.9\% of SL), smaller head length (23.9-26.4 vs $30.2 \%$ of SL), smaller orbital diameter (28.5-34.3 vs 36.9\% of HL), and deeper caudal peduncle (12.0-13.4 vs $11.6 \%$ of SL).

Furthermore, the black lateral stripe width (stripe width 1/ 2 of a scale depth $v s$ stripe width $1 / 5$ of a scale depth) and the chromatophores pattern (reticulate scales $v s$ striped scales) distinguish $A$. utiariti from the undescribed species of the Astyanax bimaculatus species sub-group with a black lateral stripe from the rio Tapajós drainage, referred by Garutti (1995).

The ichthyofauna of the upper rio Tapajós drainage (above the confluence of rio Teles Pires and rio Juruena) is poorly known. Apart from descriptions of new species, reports on the species composition of that drainage are nonexistent. During the collection expedition to several tributaries of rio Tapajós, rio Madeira, rio Purus and rio Paraguay drainages, A. utiariti was collected only in the rio Papagaio, upper rio Tapajós drainage. Garutti (1995) had also examined many lots of Astyanax from of the rio Branco-Negro, rio Juruá, rio Purus, rio Madeira, rio Tapajós, rio Xingu, and lower rio Amazonas (all tributaries of the Amazonas basin), and from rio Araguaia-Tocantins drainage. Astyanax utiariti was found only in the upper rio Tapajós. Therefore, its geographical distribution is apparentely restricted to this area.

Comparative material. Astyanax argyrimarginatus: MZUSP 48268, holotype, córrego Jaraguá, Aragarças, Goiás, Brazil. Astyanax bimaculatus: USNM 225623, 37, non-types, Kapoeri creek, Nickerie District, Surinam. Astyanax clavitaeniatus: MZUSP 5146, holotype, rio Surumu, Surumu, Roraima, Brazil. Astyanax goyacensis: MCZ 89558, holotype, MZUSP 4905, 5 topotypes, rio Vermelho, rio Araguaia basin, Goiás, Brazil. Astyanax jacuhiensis: ANSP 21912, holotype, rio Jacuí, Rio Grande do Sul, Brazil. Astyanax novae: MZUSP 68448, 6; MZUSP 68454, 6 topotypes, Cachoeira da Velha, rio Nova, rio Tocantins basin, Ponte Alta do Tocantins, Tocantins, Brazil. Astyanax rupununi: ANSP 39328, holotype; ANSP 39329, paratype, rio Rupununi, Guyana. Astyanax saltor: MNRJ 9199, holotype, rio Cachimbo, below the waterfall, rio Tapajós basin, Pará, Brazil. Astyanax siapae: MBUCV-V 29133, holotype, rio Siapa, tributary of rio Cassiquiare, Venezuela. Astyanax unitaeniatus: MZUSP 40542, holotype, ribeirão Macambira, Iaciara, Goiás, Brazil.

\section{Acknowledgments}

This paper benefited from comments and criticism by Luiz Malabarba (MCP). We thank the Centro de Microscopia e Microanálises - CEMM, PUCRS for the SEM preparations and to Alexandre Charcansky and Tiago Carvalho (MCP) for assistance with the figure of the teeth. The specimens were collected during an expedition organized by R. Reis and sponsored by the All Catfish Species Inventory (NSF-DEB 0315963). We are grateful to M. Toledo-Piza and two anonymous reviewers for comments and suggestions on the manuscript. The senior author is financially supported by the Coordenação de Aperfeiçoamento de Pessoal de Nível Superior (CAPES). Collecting permits were provided by Instituto Brasileiro do Meio Ambiente e dos Recursos Naturais Renováveis - IBAMA, Portaria 054/2004.

\section{Literature Cited}

Bertaco, V.A. \& C. A. S. Lucena. 2006. Two new species of Astyanax (Ostariophysi: Characiformes: Characidae) from eastern Brazil, with a synopsis of the Astyanax scabripinnis species complex. Neotropical Ichthyology, 4(1): 53-60.

Eigenmann, C. H. 1917. The American Characidae. Part 1. Memoirs of Museum of Comparative Zoology, 43: 1-102.

Eigenmann, C. H. 1921. The American Characidae. Part 3. Memoirs of Museum of Comparative Zoology, 43: 208-310.

Eigenmann, C. H. 1927. The American Characidae. Part 4. Memoirs of Museum of Comparative Zoology, 43: 311-428.

Fink, W. L. \& S. H. Weitzman. 1974. The so-called cheirodontin fishes of Central America with descriptions of two new species (Pisces: Characidae). Smithsonian Contributions to Zoology, 172: 1-46.

Garutti, V. 1995. Revisão taxonômica dos Astyanax (Pisces, Characidae), com uma mancha umeral ovalada e mancha no pedúnculo caudal, estendendo-se à extremidade dos raios caudais medianos, das bacias do Paraná, São Francisco e Amazônica. Unplublished Ph.D. thesis, Universidade Estadual Paulista, IBILCE-UNESP, São José do Rio Preto, SP. 286p.

Garutti, V. 1998. Descrição de uma espécie nova de Astyanax (Teleostei, Characidae) da bacia do Tocantins, Brasil. Iheringia, Sér. Zool., (85): 115-122.

Garutti, V. 1999. Descrição de Astyanax argyrimarginatus sp. n. (Characiformes, Characidae) procedente da bacia do rio Araguaia, Brasil. Revista Brasileira de Biologia, 59(4): 585-591.

Garutti, V. 2003. Revalidação de Astyanax rupununi Fowler, 1914 (Teleostei, Characidae) e descrição de duas espécies novas para o gênero. Papéis Avulsos de Zoologia, 43(1): 1-9.

Garutti, V. \& H. A. Britski. 1997. Descrição de uma espécie nova de Astyanax (Teleostei, Characidae), com mancha umeral horizontalmente ovalada, da bacia do rio Guaporé, Amazonas. Papéis Avulsos de Zoologia, 40(4): 217-229. 
Garutti, V. \& H. A. Britski. 2000. Descrição de uma espécie nova de Astyanax (Teleostei, Characidae) da bacia do alto Paraná e considerações sobre as demais espécies do gênero na bacia. Comunicações do Museu de Ciências e Tecnologia da PUCRS, Sér. Zool., Porto Alegre, 13: 65-88.

Rosen, D. E. 1972. Origin of the characid fish genus Bramocharax and a description of a second, more primitive, species in Guatemala. American Museum Novitates, (2500): 1-21.

Taylor, W. R. \& G. C. Van Dyke. 1985. Revised procedures for staining and clearing small fishes and other vertebrates for bone and cartilage study. Cybium, 9: 107-119.

Weitzman, S. H. \& L. R. Malabarba. 1998. Perspectives about the phylogeny and classification of the Characidae (Teleostei: Characiformes). Pp. 161-170. In: L. R. Malabarba, R. E. Reis, R. P. Vari, Z. M. S. Lucena, and C. A. S. Lucena (Eds.). Phylogeny and Classification of Neotropical Fishes. Porto Alegre, Edipucrs. $603 \mathrm{p}$.

Received October 2006

Accepted March 2007 